\title{
Selecting Suitable Sites for Wind Energy Development in Ghana*
}

\author{
D. Sarpong, P. E. Baffoe
}

Sarpong, D. and Baffoe, P. E. (2015), "Selecting Suitable Sites for Wind Energy Development in Ghana", Ghana Mining Journal, Vol. 16, No. 1, pp. 8 - 20.

\begin{abstract}
Recent energy crisis in Ghana has led to an intense search for an alternate energy solution. Currently the country is relying on fossil fuel for electricity generation. About $43 \%$ of energy generated in the country is from fossil fuel thermal energy. In the event of shortages in petroleum products, these power plants will have to shut down or run on a low capacity resulting in load shedding routines. In order to explore an alternate energy source, the National Renewable Energy Laboratory (NREL) conducted a study to assess Ghana's wind energy potential. Some areas across the country were found to have enough wind resource for power generation. However, sites for wind farms are not wind speed dependent only; other underlying factors also play an important role in the site selection process. The objectives of this research work are to identify these factors and integrate them in the site selection process within a GIS environment. The site selection was based on two major kinds of criteria setting; the constraints and factor criteria. Layers of these criteria setting were combined using the overlay function in a GIS environment. Weights were also assigned to the factor criteria layers using pairwise comparisons. Suitable sites were selected in five regions after incorporating the various criteria. A total of 142 isolated sites were selected after incorporating a number of factors and constraints. The optimal arrangement of the turbines for the Oforikrom site was also designed. This research recommends that the existing land use and ownership of the selected sites should be ascertained. Wind speed measuring masts should also be erected at the various sites to determine the economic viability of setting up a commercial wind farm.
\end{abstract}

Keywords: Wind Energy, Wind Farm, GIS, Criteria

\section{Introduction}

\subsection{Power Conditions in Ghana}

Over the years, Ghana has been plagued with series of power outages due to insufficient power supply by the various power generating stakeholders to meet the demands of consumers. This has significant implications on the rate of economic development. While the use of electricity for domestic purposes will normally lead to improvement in the lives of consuming individuals, productive use of electricity by industries also leads to general macro-economic improvement and a rise in the standard of living of the populace. The major consideration for Ghana is the ability of the country to match the rate of electricity demand with adequate supply (Anon., 2005).

In order to explore an alternate energy source for electricity generation, the National Renewable Energy Laboratory (NREL) in partnership with the Energy Commission of Ghana and Meteorological Service Department conducted a study to assess Ghana's wind power potential both on-shore and off-shore. The study, which was known as the Solar and Wind Energy Resource Assessment (SWERA), concluded that Ghana has Class 4-6 wind resources (with Class 6 being the highest wind resource potential and Class 1 being the lowest) at the highest ridges near the border with Togo and the highest ridges northwest of Accra (Mallet, 2012).

However, according to the SWERA Report, the assessment did not take into consideration other limiting factors such as land-use restrictions, nearness of the wind resource to power transmission lines and accessibility (Anon., 2005a). This research work, therefore, is incorporating these and other limiting factors to refine the search area available for harnessing wind energy.

\subsection{Energy and Electricity}

Electricity generation is one of the key factors in the achievement of rapid economic growth (Anon., 2013). In Ghana, it plays an important role in the country's economy by powering its industrial, commercial and urban development (Anon., 2005b).

Ghana generates electricity from hydropower, fossil fuel thermal energy and renewable energy sources (Anon., 2013). About 56\% of this energy generated is from hydropower and $43 \%$ from fossil fuel thermal energy. The country's electricity 
generating plants and their installed capacity as at 2014 are shown in Table 1.

Table 1 Installed Capacity and other Plants as at 2014

\begin{tabular}{|l|r|l|l|}
\hline Plants & $\begin{array}{r}\text { Installed } \\
\text { Capacity } \\
\text { (MW) }\end{array}$ & Type & \multicolumn{1}{|c|}{$\begin{array}{c}\text { Fuel } \\
\text { Type }\end{array}$} \\
\hline Akosombo & 1020 & Hydro & Water \\
\hline Kpong & 160 & Hydro & Water \\
\hline $\begin{array}{l}\text { TAPCO } \\
\text { (T1) }\end{array}$ & 330 & Thermal & LCO/Gas \\
\hline TICO (T2) & 220 & Thermal & LCO/Gas \\
\hline T3 & 132 & Thermal & LCO/Gas \\
\hline TT1PP & 110 & Thermal & LCO/Gas \\
\hline TT2PP & 49.5 & Thermal & DFO/Gas \\
\hline MRP & 80 & Thermal & DFO \\
\hline Solar & 2 & Renewable & Solar \\
\hline $\begin{array}{l}\text { Sunon } \\
\text { Asogli }\end{array}$ & 200 & Thermal & Gas \\
\hline CENIT & 110 & Thermal & LCO/Gas \\
\hline Bui HEP & 400 & Hydro & Water \\
\hline Total & $\mathbf{2 ~ 8 1 3 . 5}$ & & \\
\hline
\end{tabular}

(Source: Anon., 2014a)

Legend:

LCO - Light Crude Oil

DFO - Distillate Fuel Oil

TAPCO - Takoradi Power Company

TICO - Takoradi International Company

TT1PP - Tema Thermal 1 power plant

TT2PP - Tema Thermal 2 power plant

MRP - Mines Reserve Plant

\subsection{Electricity Demand and Future Plans}

Demand for electricity increased at an average growth of $6 \%$ per year between 2000 and 2010 . This is expected to rise to $7 \%$ by 2020 (Antwi, 2011). In view of this, the VRA has devised a number of measures to accommodate the future demands. These measures include four large scale hydro plants, a wind farm and a solar power plant with planned capacities of 219, 100-150 and 10 MW respectively (Antwi, 2011). It is, however, a policy of the Ministry of Energy to have 10\% of Ghana's energy mix come from renewable sources (excluding large-scale hydro) by 2020 (Mallet, 2012; Mahu and Mawufemo, 2012)

In 2011, the Parliament of Ghana passed the Renewable Energy Law (Act 832). The Act provides for the development, management and utilisation of the renewable energy sources for the production of heat and power.

\subsection{Energy Resource}

Wind energy has been used by humans for centuries to move boats, grind grain and pump water. In modern civilization, winds are being exploited by converting its energy to electricity. Wind energy is one of the lower-impact forms of electricity generation in terms of its benefits outlined at the regional and global level. It produces no air or water pollution and since wind is free, operational costs are nearly zero once a turbine is erected (Anon., 2014b).

Arrays of large turbines, known as wind farms, are becoming an increasingly important source of renewable energy and are used by many countries as part of a strategy to reduce their reliance on fossil fuels.

Wind energy available at any location is measured by a quantity known as Wind Power Density (WPD) (Anon., 2014c). It is determined by calculating the average annual power available per square meter of swept area of a turbine, and is tabulated for different heights above ground. The calculated WPD are included in an index developed by the NREL and referred to as "NREL CLASS" (see Table 2). The larger the WPD calculation, the higher it is rated by class. Classes range from Class $1\left(200 \mathrm{~W} / \mathrm{m}^{2}\right.$ or less at $50 \mathrm{~m}$ altitude) to Class 7 ( 800 to $2000 \mathrm{~W} / \mathrm{m}^{2}$ ). Commercial wind farms are generally sited in Class 3 or higher areas (Anon., 2014d). The wind power density calculation also includes the effect of wind velocity and air density

Table 2 NREL Wind Power Class

\begin{tabular}{|c|c|c|}
\hline \multirow{2}{*}{$\begin{array}{c}\text { Wind } \\
\text { Power Class }\end{array}$} & \multicolumn{2}{|c|}{$\mathbf{5 0}$ m above ground } \\
\cline { 2 - 3 } & $\begin{array}{c}\text { Wind Power } \\
\text { Density }\left(\mathbf{W} / \mathbf{m}^{\mathbf{2}}\right)\end{array}$ & $\begin{array}{c}\text { Speed } \\
\mathbf{( m / s )}\end{array}$ \\
\hline 1 & 0 & 0 \\
\hline 2 & 200 & 5.6 \\
\hline 3 & 300 & 6.4 \\
\hline 4 & 400 & 7.0 \\
\hline 5 & 500 & 7.5 \\
\hline 6 & 600 & 8.0 \\
\hline \multirow{2}{*}{7} & 800 & 8.8 \\
\cline { 2 - 3 } & 2000 & 11.9 \\
\hline
\end{tabular}

(Source: Anon., 2014)

\subsection{Potential Environmental and Social Impacts of Wind Power Development}

In spite of these advantages, a number of concerns have been raised about the impact of wind turbines on the populace (Nkrumah, 2002).

\section{Land Requirements}

Wind farms require a large land area due to the requirement that the individual turbines in a wind farm must be spaced well apart to avoid 
interference. In most instances, however, activities such as farming and ranching can go on relatively unimpeded within the wind farm site.

\section{Noise}

Noise from wind turbines comes primarily from the rotor blades as they slice through the air. Although wind machines built recently make substantially less noise than earlier models, noise from wind machines is potentially a problem if wind farms are sited too close to residences.

\section{Bird Strikes}

Birds can fly into fast-moving rotor blades of wind machines and be killed. While evidence to date indicates that birds generally learn to avoid the spinning rotors, some problems with bird strikes have been noted.

\section{Interference with Telecommunications}

Wind turbines interfere with television (mostly) and other telecommunications signals, but these impacts seem to typically be localized to the vicinity of the wind farm.

\section{Safety}

Like any industry that includes moving machinery, safety is an issue with wind farm. Particular hazards from equipment failure include injury from equipment failures such as blades breaking off. Safety issues have been taken into account in wind turbine design, however, and there have been no reported public injuries from wind energy.

\section{Visual Impacts}

The presence of wind turbines produce changes in views and skylines, and thus have a visual impact on the area in which they are cited. Visual impacts may be an especially important consideration if the turbines are to be located in pristine or wilderness areas. The access roads and power lines needed for grid-connected turbines can cause additional aesthetic impacts.

\subsection{NREL's Wind Resource Assessment}

The National Renewable Energy Laboratory also conducted an assessment of Ghana's wind energy resource between 2002 and 2005. The assessment was part of the SWERA project for the United Nations Environment Programme. Several global data sets maintained at NREL, including surface and upper-air observations spanning many years of record, were used in the assessment.

The NREL used surface datasets from the 22 synoptic stations operated by the MSD as well as wind data from the Energy Commission (EC) measured at 10 sites along the coast of Ghana.

The data from MSD were not generally useful for assessing wind resource at $50 \mathrm{~m}$ a.g.l since the anemometers were only $2 \mathrm{~m}$ a.g.l (Anon., 2005c). The wind speeds were, therefore, extrapolated to 12 $\mathrm{m}$ and $50 \mathrm{~m}$ a.g.l for the assessment.

Satellite ocean wind data as well as Upper-Air Data from observations and computer model-derived were also used for the assessment. A wind density map for Ghana was produced at the end of the project.

NREL's assessment identified a number of locations across the country with higher wind energy potential based on the wind speed map generated. However, site locations for wind farms are not wind speed dependent only; other underlying factors, with various degree of importance, need to be combined with the wind speed data to select a more suitable and feasible site.

\subsection{Wind Farm Site Selection Criteria}

Site selection for large wind turbine requires the consideration of a comprehensive set of factors and the balancing of multiple objectives in determining the suitability of a particular area (Bennui et al., 2007). These factors are necessary, due to the impact the wind turbines may have on the existing land uses, environment and communities.

\subsubsection{Criteria for Other Wind Farm Site Selection Projects}

Neufville (2013) carried out a project of selecting suitable sites for wind farms in Jamaica using Multi-Criteria Analysis (MCA) and Geographic Information System (GIS). He considered the wind speed, accessibility by trucks, land ownership, proximity to high voltage transmission grid, the topography of the site, the required distance from dwellings and the suitability of soil conditions and foundations.

Bennui et al. (2007) used Geographic Information System (GIS) to select sites for large wind turbines in Thailand. They adopted the following criteria for the selection:

(i) Reservation areas in 1st class watershed;

(ii) Areas of elevation higher than $200 \mathrm{~m}$ above ground

(iii) Hilly areas steeper than $15 \%$ slope; Reservation areas in 1st class watershed

(iv) Buffer zones within $2.5 \mathrm{~km}$ from urban area; 
(v) Buffer zones within $1.0 \mathrm{~km}$ from rural communities;

(vi) Buffer areas within $2 \mathrm{~km}$ from important places;

(vii) Safety areas $1.0 \mathrm{~km}$ around tourist places;

(viii) Safety areas $3.0 \mathrm{~km}$ from airports

(ix) Safety trips $0.5 \mathrm{~km}$ offset from highways

(x) Nature safety zones within $200 \mathrm{~m}$ from water bodies and main rivers

The European Wind Energy Association (EWEA) is a professional association for institutions and industries involved in wind energy research and development. The association's publication, "European best practice guidelines for wind energy development", outlined a number of factors that should be considered in siting wind farms (Anon., 2002). Their criteria were grouped into environmental and technical considerations as shown in Table 3.

Table 3 EWEA Site Selection Criteria for Wind Farms.

\begin{tabular}{|l|l|}
\hline $\begin{array}{l}\text { Environmental } \\
\text { Considerations }\end{array}$ & $\begin{array}{l}\text { Technical } \\
\text { Considerations }\end{array}$ \\
\hline Visual Aspect & Wind resource \\
\hline Proximity to dwellings & Existing land uses \\
\hline Ecology & Ground conditions \\
\hline $\begin{array}{l}\text { Archaeological/historical } \\
\text { heritage }\end{array}$ & Site access \\
\hline $\begin{array}{l}\text { Recreational uses of } \\
\text { surrounding land) }\end{array}$ & $\begin{array}{l}\text { Electrical } \\
\text { connection }\end{array}$ \\
\hline Telecommunications & Draft project design \\
\hline Civil and military airports & \\
\hline Restricted areas & \\
\hline
\end{tabular}

\subsubsection{MCDM and Analytical Hierarchy Process}

Multiple Criteria Decision Making (MCDM) refers to making decisions in the presence of multiple, usually conflicting, criteria (Xu and Yang, 2001). Each criterion has a particular level of importance in the final decision hence the need to quantify them. This can be achieved using Analytical Hierarchy Process (AHP).

The AHP is a theory of measurement through pairwise comparisons and relies on the judgements of experts to derive priority scales. The comparisons are made using a scale of absolute judgements that represents how much more one element dominates another with respect to a given attribute (Saaty, 2008).

Selecting suitable sites for wind farms is a MCDM. The various factors adopted for this study will be quantified using the pairwise comparison.

\subsubsection{Geographic Information System (GIS)}

GIS is a system designed to capture, store, manipulate, analyse, manage, and present all types of geographical data (Kumi-Boateng, 2013). A GIS-based framework helps us gain a scientific understanding of earth systems at a truly global scale and leads to more thoughtful, informed decision making (Dangermond and Baker, 2010). It provides the decision-maker with a powerful set of tools for the manipulation and analysis of spatial information (Carver, 1991). Due to this capability, GIS can be used to undertake site suitability studies by overlaying a number of factor maps or layers

\subsection{Site Selection Criteria for this Project}

According to Eastman et al. (1995), there are two kinds of criteria that support decision-making. They are the constraint and factor criteria. The criteria setting for this study are based on the two kinds of criteria.

\subsubsection{Constraint Criteria}

The constraints are based on the Boolean criteria, which limit the alternatives under consideration to specific regions. They are expressed in the form of a Boolean (logical) map where areas excluded from the consideration (i.e. unsuitable areas) are coded with the value 0 and those open for consideration (i.e. suitable areas) are coded 1 (Chaudhry, 2008; Eastman et al., 1995). The following are the constraints set out for this study:

(i) Siting is restricted to regions $2 \mathrm{~km}$ away from Urban Areas. This is to reduce the visual impact of the turbines on residents (Talinli et al., 2011).

(ii) Regions that are $250 \mathrm{~m}$ away from streams and rivers are suitable for wind farms.

(iii) Wind farms cannot be sited in protected areas such as forest and game reserves, tourist sites, etc.

(iv) Siting in lakes is restricted.

(v) Slopes greater than $30^{\circ}$ are unsuitable for siting. They create undesirable wind turbulence, decrease accessibility through roads and increase construction costs (Chaudhry, 2008). 


\subsubsection{Factor Criteria}

The factors are criteria, which define some degree of suitability for all the geographic regions. They enhance the suitability of a specific alternative for the activity under consideration. It is therefore measured on a continuous scale of suitability. The following factors were adopted for this study based on consistency in literature and the availability of data:

\section{The wind resource available}

The availability of wind resource is paramount for the use of electricity generation. A viable wind power project requires regular and sufficient wind speed at the hub height of the turbines. For commercial wind farms, class 3 or higher wind resource (i.e. wind resource greater than $300 \mathrm{~W} / \mathrm{m}^{2}$ ) are more suitable (Anon, 2014d).

\section{Land use restrictions}

The existing land use of an area with adequate wind resource also plays an important role in selecting a suitable wind farm site. For instance, there are areas where no wind farms can be built although sufficient wind resource exists in those areas. Such areas include forests, wetlands, archaeological sites, aviation and military zones (Talinli et al., 2011). These constraints are related to the land use and the existing condition of the land. Grasslands and bare lands are highly preferred.

Proposed land use also affects the decision to site a wind farm. Beneficial land uses for the public such as agriculture, potential residential or industrial area and tourism cause obstructions and more detailed analysis of the decision (Talinli et al., 2011). Proposed land uses were, however, not considered for this study.

\section{Proximity to towns}

Wind turbines are sited at a suitable distance away from dwellings in order to eliminate or reduce the unpleasant effect of shadow flickers on dwellers. Shadow flickers are created when the blades of the turbines cut through the sun's rays (Talinli et al., 2011; Klepinger, 2007). These recurring shadows create undesirable visual effects on people when they fall on inhabited structures, hence the need to site wind farms away from dwellings.

The turbines are also sited away from towns due to noises created from the motion of the wind turbine's mechanical components. Low frequency sounds are also generated from the interaction of the turbine's blades with the airflow. Noise levels up to $50 \mathrm{~dB}(\mathrm{~A})$ are permitted during the day (Moiloa, 2009). For this project, wind farm sites will be more suitable at distances greater than $1 \mathrm{~km}$ from major towns to reduce the effects of shadow flickers and noise on people.

\section{Proximity to roads}

The site should be accessible by roads for the transportation of the turbine components, construction materials and other equipment. The maximum distance by which the site can be accessed must be suitable (i.e. distances not more than $2 \mathrm{~km}$ away from major roads). Distances greater than $2 \mathrm{~km}$ are less suitable and must be avoided.

\section{Proximity to transmission lines}

Building new transmission lines are expensive hence the need to site wind farms at a suitable distance closer to transmission lines. Distances between 250 and $5250 \mathrm{~m}$ are extremely suitable.

\section{Slope}

Gradual slopes cause an increase in wind speed and road accessibility. Construction is also more feasible on gentle slopes. Slope angles lesser than $30^{\circ}$ are highly suitable (Chaudhry, 2008).

\section{Elevation}

For efficient energy generation, wind turbines must be located in open areas and on higher elevations than the surrounding area, preferably, elevations greater than $100 \mathrm{~m}$.

Proximity to airports

Wind turbines may interfere with radio transmissions, radar and microwave signals due to their heights hence the need to site them away from airports. A minimum distance of $5 \mathrm{~km}$ away from airports is more suitable.

\section{Resources and Methods Used}

\subsection{Study Area}

Ghana is a sovereign state with a population of 24.7 million (Anon., 2012) and lies between latitudes $4^{\circ} \mathrm{N}$ and $12^{\circ} \mathrm{N}$, and longitudes $4^{\circ} \mathrm{W}$ and $2{ }^{\circ} \mathrm{E}$. It is bounded on the north and northwest by Burkina Faso (Upper Volta), on the east by Togo, on the south by the Atlantic Ocean, and on the west by Côte d'Ivoire. Fig. 1 is a map of the study area.

Ghana has a land area of $238535 \mathrm{~km}^{2}$ and an Atlantic coastline that stretches $560 \mathrm{~km}$ along the Gulf of Guinea (Anon., 2013). Its territorial waters extend $200 \mathrm{NM}$ into the sea. 


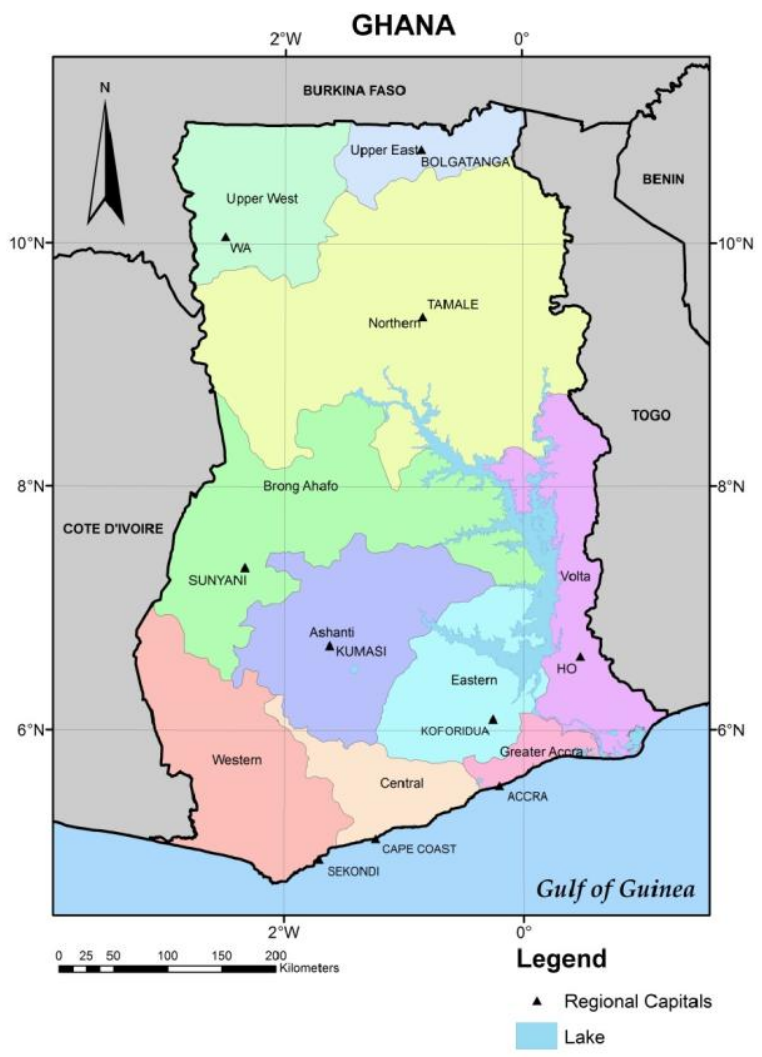

Fig. 1 Map of Study Area

\subsection{Data Used}

Some of the data used for this research work as well as their sources are listed in Table 4. Most of these datasets were obtained from the Geomatic Engineering Department of the University of Mines and Technology (UMaT), Tarkwa.

\section{Table 4 Data Used and their Sources}

\begin{tabular}{|l|l|}
\hline \multicolumn{1}{|c|}{ Data } & \multicolumn{1}{c|}{ Source } \\
\hline Wind Resource & NREL website \\
\hline Boundary & $\begin{array}{l}\text { Geomatic Engineering } \\
\text { Department (GED) of the } \\
\text { University of Mines and } \\
\text { Technology (UMaT). }\end{array}$ \\
\hline Land Cover & GED, UMaT \\
\hline Roads & GED, UMaT \\
\hline Towns & GED, UMaT \\
\hline $\begin{array}{l}\text { Rivers, Lakes and } \\
\text { Lagoons }\end{array}$ & GED, UMaT \\
\hline $\begin{array}{l}\text { Airports } \\
\text { Airfield locations }\end{array}$ & GED, UMaT \\
\hline Protected Areas & GED, UMaT \\
\hline $\begin{array}{l}\text { Transmission } \\
\text { Lines }\end{array}$ & NREL Geospatial Toolkit \\
\hline DEM & $\begin{array}{l}\text { U.S Geological Survey } \\
\text { (USGS) EarthExplorer } \\
\text { website }\end{array}$ \\
\hline
\end{tabular}

\subsection{Methods}

The following data preparation activities were carried out:

(i) Most of the vector datasets such as the "Land Cover" data were converted to raster files due to the type of file format requirement by some of the geoprocessing tools.

(ii) The cell sizes of some raster datasets were also reduced to achieve high resolution results. The $1 \mathrm{~km} \mathrm{x} 1 \mathrm{~km}$ cell size of the wind resource data, for instance, was converted to a $50 \mathrm{~m} \mathrm{x}$ $50 \mathrm{~m}$ cell size.

(iii) Some datasets such as the wind resource and the transmission lines were masked or clipped by the country's boundary data. This is to limit the data processing within the boundary.

(iv) Datasets with different coordinate systems were also converted to the Ghana Meter Grid coordinate system

\subsubsection{Creating the Constraint Map}

The constraint map was created based on the constraint criteria. The processes for obtaining the constraint map are summarised in Fig. 2.

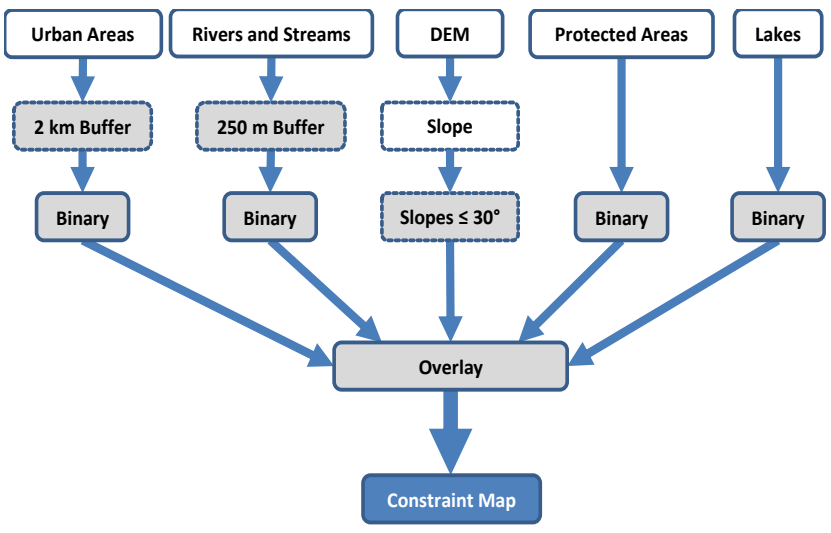

Fig. 2 A Flow Chart of the Processes Used to Obtain the Constraint Map

A $2 \mathrm{~km}$ buffer of urban areas as well as a $250 \mathrm{~m}$ buffer of streams and rivers was created using the "Buffer" tool in ArcGIS. A slope layer was generated from the DEM of which slopes less than30 degrees were created using the "Raster Calculator" tool. All the constraint datasets were converted to binary form exhibiting raster values of 0 and 1 , where 0 represents unsuitable areas and 1 represents suitable Areas. 


\subsubsection{Creating the Factor Map}

The factor map was created based on the factor criteria specified in sub-heading 4.2.2. The processes are shown in Fig. 3.

\section{Euclidean Distance}

Euclidean distances were created for the road networks, towns, airports and the transmission lines data. This was to enable the various distances created around each data to be classed to a desired range and scale.

\section{Slope}

The slope of the terrain was necessary to identify areas of gradual gradient which are of interest to the site selection process. It was generated from the ASTER GDEM using the slope tool in the 'Surface' toolset of the 'Spatial Analyst' toolbox.

\section{Reclassification}

All the factor datasets including the Land Cover were reclassified to a desired range and represented with new raster values. The wind resource, for instance, was classified according to NREL's Wind Power Class.

\section{Weighting}

The table was represented by an $8 \times 8$ matrix and then multiplied by itself to obtain an eigenvector. This was then normalised by summing the eigenvector and dividing each value of the Eigen
Pairwise comparison was used to assign weights to the individual map layers of the factor criteria. The importance of each factor criterion over the other was determined and quantified. The comparisons were quantified on a scale of 1 to 9 . The quantity, 1 , represents two factors of equal importance; 9, denotes a factor with extreme importance over the other (Saaty, 2008). Based on literature as well as advice from experts, the judgements in Table 5 were obtained.

Table 5 The Judgments Table

\begin{tabular}{|c|c|c|c|c|c|c|c|c|}
\hline & $\frac{\pi}{3}$ & U્ય & 㦴 & 茨 & 三 & $\overrightarrow{\vec{s}}$ & 贫 & $\mathbb{a}$ \\
\hline WR & 1 & 2 & 3 & 4 & 4 & 5 & 6 & 8 \\
\hline LC & $1 / 2$ & 1 & 2 & 3 & 3 & 5 & 6 & 7 \\
\hline PT & $1 / 3$ & $1 / 2$ & 1 & 2 & 2 & 4 & 5 & 7 \\
\hline PR & $1 / 4$ & $1 / 3$ & $1 / 2$ & 1 & 1 & 2 & 5 & 6 \\
\hline TL & $1 / 4$ & $1 / 3$ & $1 / 2$ & 1 & 1 & 2 & 3 & 4 \\
\hline SLP & $1 / 5$ & $1 / 5$ & $1 / 4$ & $1 / 2$ & $1 / 2$ & 1 & 2 & 3 \\
\hline ELV & $1 / 6$ & $1 / 6$ & $1 / 5$ & $1 / 5$ & $1 / 3$ & $1 / 2$ & 1 & 2 \\
\hline $\mathbf{P A}$ & $1 / 8$ & $1 / 7$ & $1 / 7$ & $1 / 6$ & $1 / 4$ & $1 / 3$ & $1 / 2$ & 1 \\
\hline
\end{tabular}

vector by the sum. The weights for the individual factors were obtained after the normalisation process. The process was, however, iterated a number of times until the weights assigned to each factor were consistent.

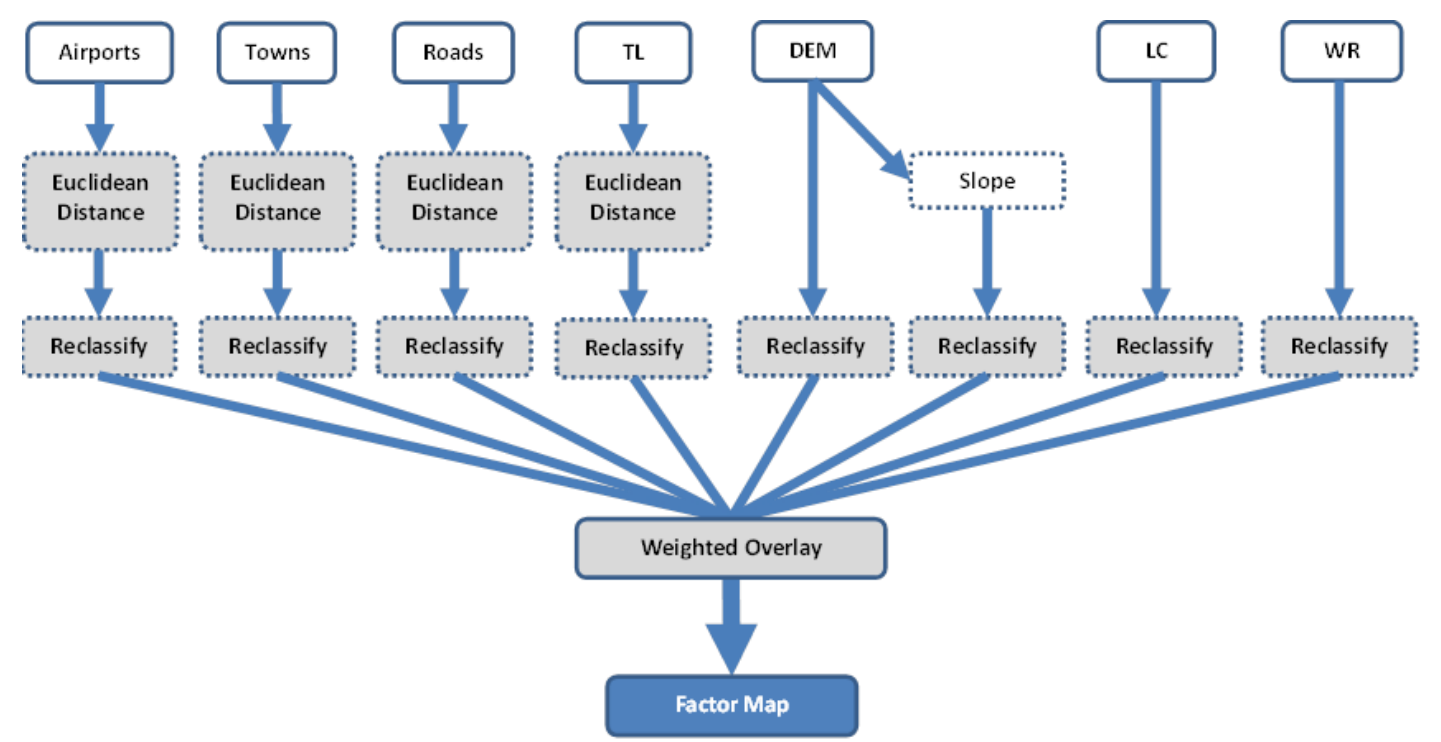

Fig. 3 A Flow Chart of the Processes Used to Derive the Factor Map 
A consistency ratio of 0.026082 was achieved which is less than the maximum allowable ratio of 0.10 .

The final weights obtained in Table 6 were assigned to the reclassified factor layers in the weighted overlay tool.

Table 6 Weights of the Factor Criteria

\begin{tabular}{|l|l|r|r|}
\hline \multicolumn{2}{|c|}{ Factors } & Weights & $\begin{array}{c}\text { Weights } \\
(\%)\end{array}$ \\
\hline Wind Resource & WR & 0.3196 & 32 \\
\hline Land Cover & LC & 0.2273 & 23 \\
\hline Proximity to Towns & PT & 0.1564 & 16 \\
\hline Proximity to Roads & PR & 0.1010 & 10 \\
\hline Transmission Lines & TL & 0.0870 & 9 \\
\hline Slope & SLP & 0.0517 & 5 \\
\hline Elevation & ELV & 0.0339 & 3 \\
\hline Proximity to Airports & PA & 0.0231 & 2 \\
\hline Total & & 1 & $\mathbf{1 0 0}$ \\
\hline
\end{tabular}

\section{Weighted Overlay}

The weighted overlay tool overlays several raster datasets using a common measurement scale and weights each according to its importance. This tool was used to derive the final suitability map. The input raster datasets were the reclassified factor layers with their influence obtained from the pairwise comparison. A measurement scale of 1 to 9 was used with 1 implying "Highly unsuitable" and 9 meaning "Extremely suitable".

\subsubsection{Final Suitable Sites}

The final selection process of the suitable sites is depicted in Fig. 4. The highly suitable areas were selected from the factor map and converted to the binary form (i.e. raster dataset exhibiting values of 0 and 1) using the 'Raster Calculator' tool. The intersection of the suitable areas of the constraint map and the binary factor map was achieved using the 'Boolean And' tool. This tool returns a binary result of two input rasters. If both input values are true (non-zero), the output value is 1 . If one or both inputs are false (zero), the output is 0 .

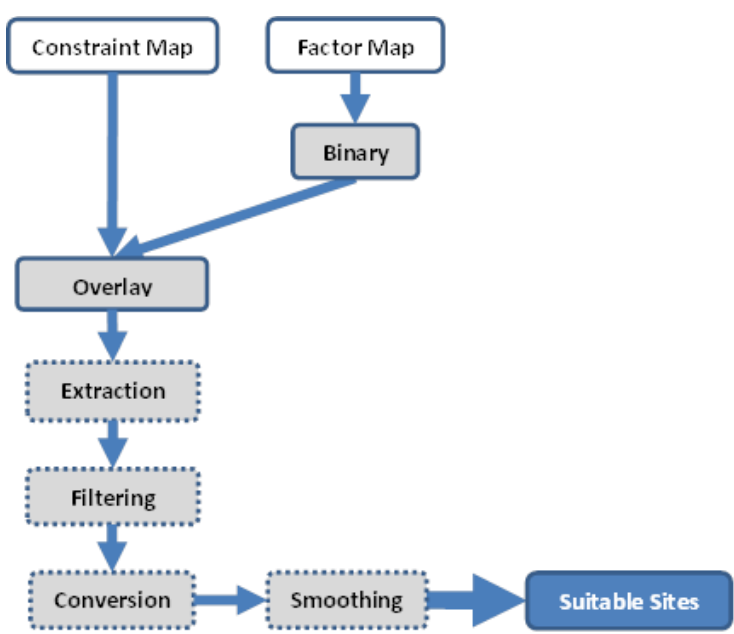

Fig. 4 A Flow Chart of the Final Processes Used to Obtain the Suitable Sites

\section{Extraction}

The suitable regions, with a raster value of 1 after the intersection, were extracted using the 'Extract By Attribute' tool.

\section{Filtering}

Filtering was done to replace cells in the extracted raster based on the majority of their adjoining neighbouring cells. The 'Majority Filter' tool of the Generalisation toolset was used with a neighbourhood number of 'EIGHT' and a 'MAJORITY' replacement threshold.

\section{Conversion}

The filtered selections were converted from raster to polygons using the 'Raster to Polygon' tool in the 'Conversion' toolsets.

\section{Smoothing}

The edges of the polygons were smoothened using the Polynomial Approximation with Exponential Kernel (PAEK) algorithm with a smoothing tolerance of $200 \mathrm{~m}$.

\section{Other Processes}

Sites with areas less than $12000 \mathrm{~m}^{2}$ are not suitable for commercial wind farms and were therefore removed from the final selection.

Closer sites separated by a distance of $150 \mathrm{~m}$ were aggregated using the 'Aggregate Polygons' tool. Also sites within the same vicinity were grouped by dissolving similar name fields of the final selection's attribute. 


\section{Results and Discussion}

\subsection{Results}

\subsubsection{Buffer and Binary Map}

Fig. 5 shows the binary form of the $2 \mathrm{~km}$ buffered urban areas based on the Boolean constraint. The white areas are unsuitable whereas the green areas are suitable.

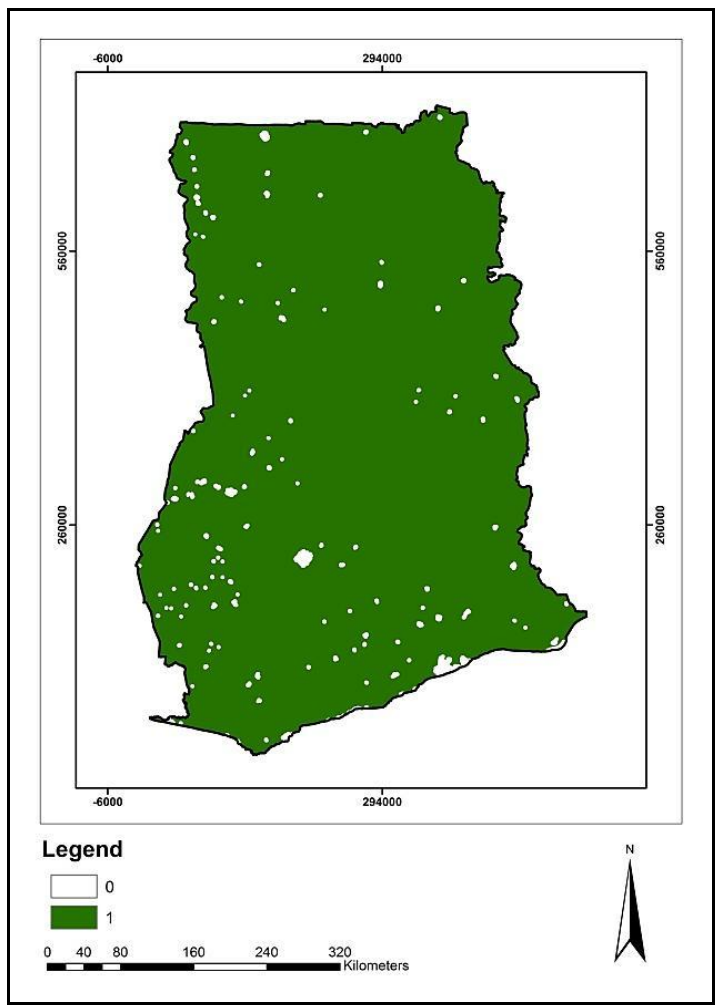

Fig. 5 Binary Form of Buffered Urban Areas

\subsubsection{Euclidean Distance and Reclassify map}

In Fig. 6 the different colour symbols represent the various distances away from the transmission line dataset. The distances were created for 10 classes at equal intervals of $17369.79 \mathrm{~m}$.

\subsubsection{The Constraint Map}

Fig. 7 shows the constraint map created in SubHeading 4.3.1 based on the constraint criteria. The final image produced was in binary form. The green colour code, which has a raster value of 1 , represents areas suitable for wind farms; the white areas are unsuitable.

\subsubsection{Factor Map}

The final suitability map shows the various degrees of suitable areas (Fig. 8). The dark red areas are restricted areas; siting cannot occur in these areas. The deep green areas are extremely suitable but only occupy an area of $18.58 \mathrm{~km}^{2}$. The highly and extremely suitable regions are, therefore, desired for the purposes of this study.

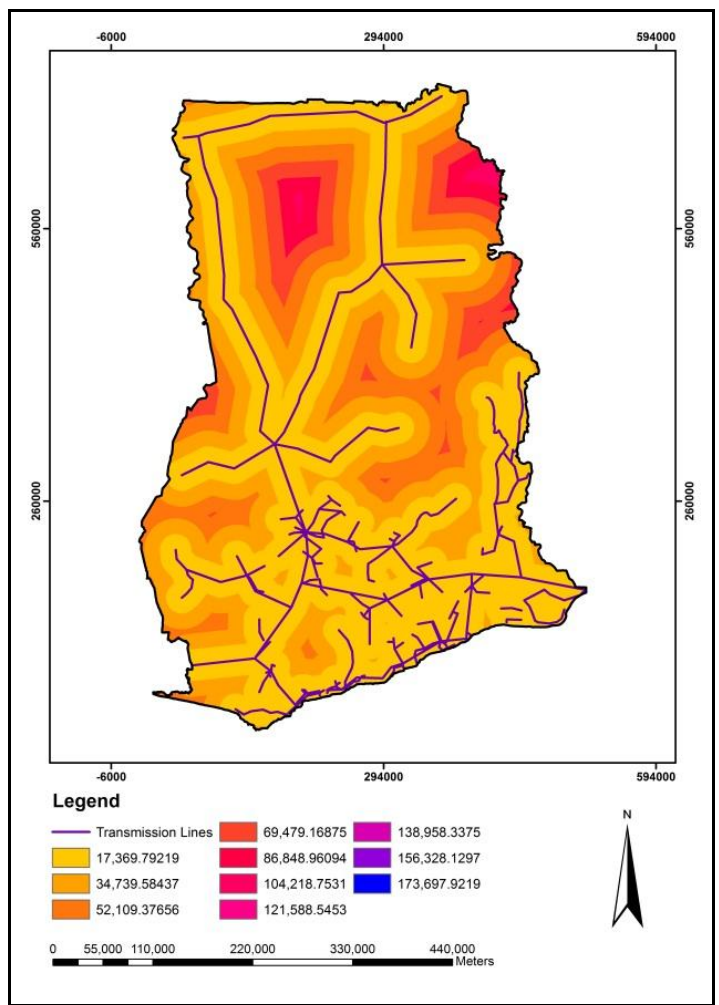

Fig. 6 Euclidean Distance of the Transmission Lines

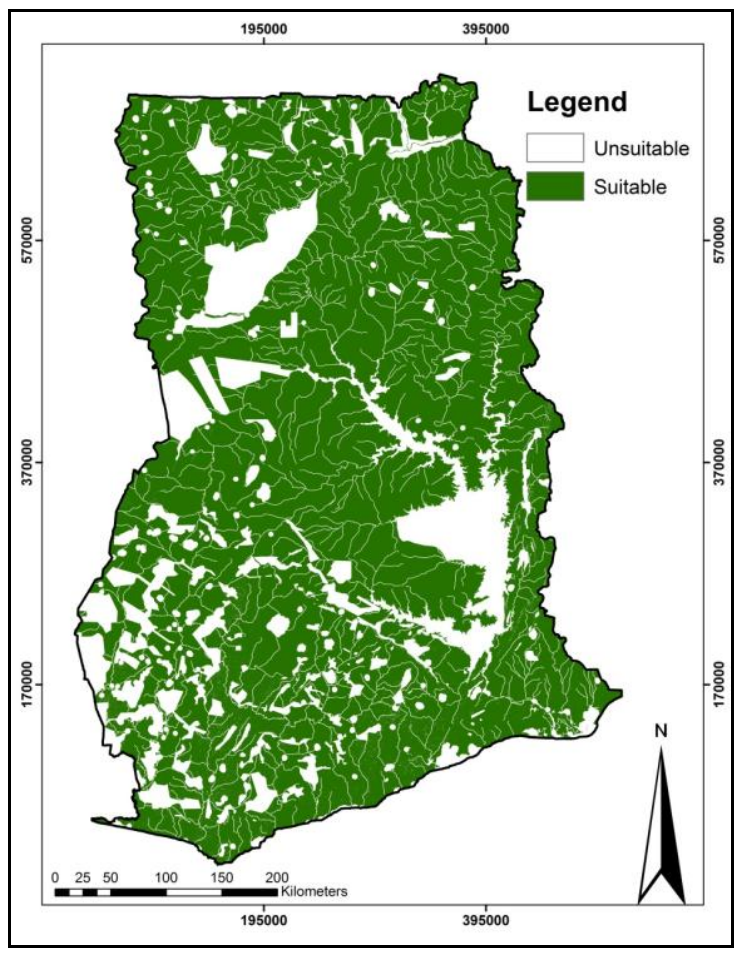

Fig. 7 The Constraint Map 


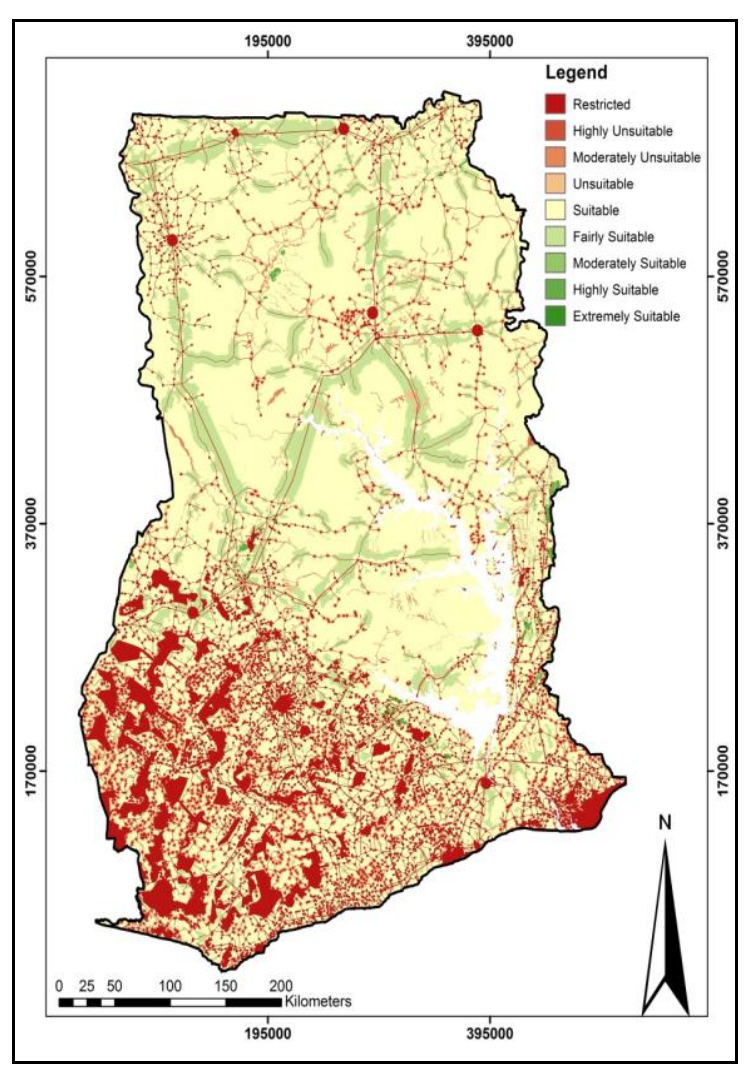

Fig. 8 The Factor Map

\subsubsection{Final Selection}

The selected suitable region from the factor map (Fig. 9) has an area of $647.55 \mathrm{~km}^{2}$. However, after the intersection with the constraint map using the 'Boolean And' tool, the area of the suitable region reduced to $452.23 \mathrm{~km}^{2}$.

The filtering process further increased the area to $453.53 \mathrm{~km}^{2}$ due to the majority neighbourhood setting. Cells were replaced based on the large numbers of adjoining cells with the same value. Isolated and scattered cells were also removed as a result of the filtering process. Fig. 10 shows the selection after the constraint map and the factor map was overlayed and filtered.

After areas less than $12000 \mathrm{~m}^{2}$ were removed, the area of the selection reduced to $452.70 \mathrm{~km}^{2}$. However, this increased to $454.65 \mathrm{~km}^{2}$ after aggregating sites within a distance of $150 \mathrm{~m}$.

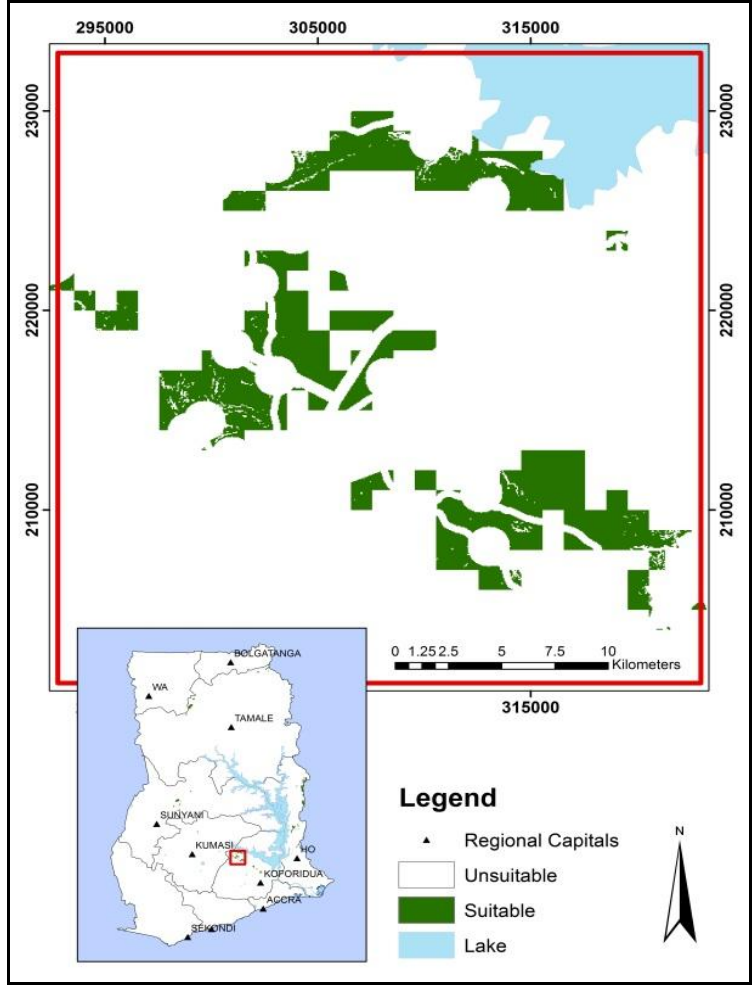

Fig. 9 Suitable Sites Selected from Factor Map

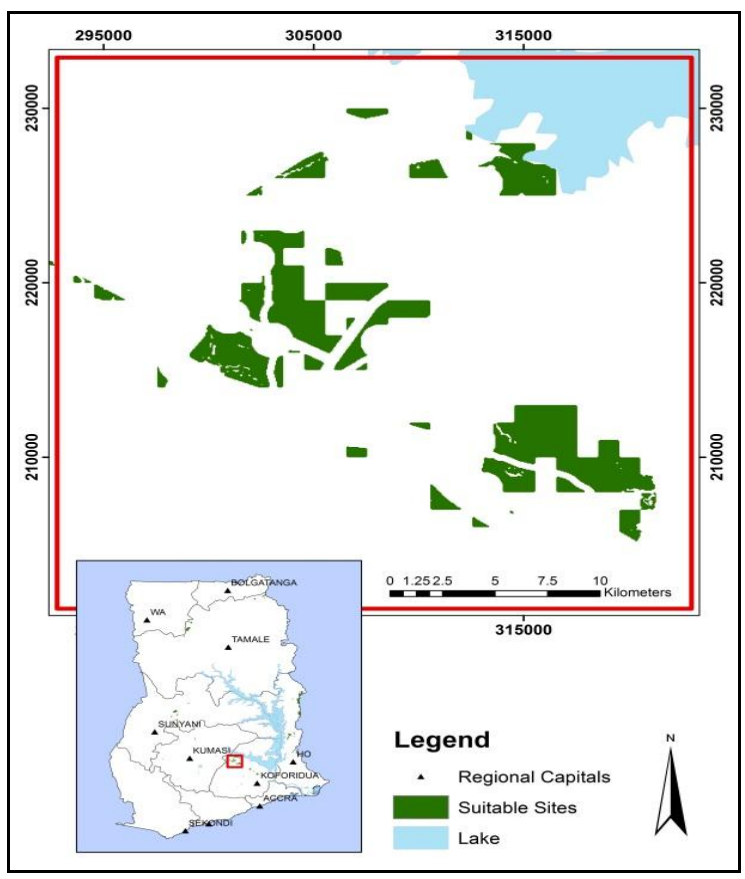

Fig. 10 Filtered Suitable Sites

\subsection{Discussion}

The final site selection process resulted in the selection of 142 isolated sites. This, however, reduced to 76 after regrouping sites within the same locality. The largest site has an area of 62.082 $\mathrm{km}^{2}$ located in the Volta Region near Salifukrom. The smallest site is also located in the Volta Region $1.4 \mathrm{~km}$ away from Teteman. It has an area of 
$0.03947 \mathrm{~km}^{2}$. Table 7 shows a sample of the selected sites.

Table 7 A Sample of the Selected Sites

\begin{tabular}{|l|l|l|l|l|}
\hline $\begin{array}{c}\text { Site } \\
\text { ID }\end{array}$ & Region & $\begin{array}{c}\text { Closest } \\
\text { Town }\end{array}$ & $\begin{array}{c}\text { Distance } \\
\text { from } \\
\text { Closest } \\
\text { Town } \\
(\mathbf{m})\end{array}$ & $\begin{array}{c}\text { Area } \\
\left(\mathbf{k m}^{\mathbf{2}}\right)\end{array}$ \\
\hline Site 3 & Ashanti & Kofiase & 2153.97 & 2.344 \\
\hline Site 9 & $\begin{array}{l}\text { Brong } \\
\text { Ahafo }\end{array}$ & Oforikrom & 1035.41 & 5.378 \\
\hline Site 22 & Eastern & Appiakrom & 1305.31 & 22.809 \\
\hline Site 45 & Northern & Sakogu & 2173.47 & 9.1940 \\
\hline Site 71 & Volta & Salifukrom & 1424.90 & 62.082 \\
\hline Site 75 & Volta & Teteman & 1409.67 & 0.0395 \\
\hline
\end{tabular}

The Volta Region recorded the largest number of sites (59 isolated sites) occupying a total area of $226.0212 \mathrm{~km}^{2}$. A section of the selected sites in the Volta Region is shown in Fig. 11. The Ashanti Region has the least number of isolated sites with a total area of $6.8694 \mathrm{~km}^{2}$. A regional summary of the number of selected sites is shown in Table 8 .

Table 8 Regional Summary of the Number of Sites Selected

\begin{tabular}{|l|c|c|c|}
\hline \multicolumn{1}{|c|}{ Region } & $\begin{array}{c}\text { Number of } \\
\text { Isolated sites }\end{array}$ & $\begin{array}{c}\text { Number of } \\
\text { regrouped Sites }\end{array}$ & $\begin{array}{c}\text { Total Area of } \\
\left.\text { sites } \mathbf{( k m}^{2}\right)\end{array}$ \\
\hline Ashanti & 5 & 3 & 6.8694 \\
\hline Brong Ahafo & 24 & 11 & 81.6236 \\
\hline Eastern & 47 & 28 & 110.0956 \\
\hline Northern & 7 & 3 & 30.0357 \\
\hline Volta & 59 & 31 & 226.0212 \\
\hline Total & $\mathbf{1 4 2}$ & $\mathbf{7 6}$ & $\mathbf{4 5 4 . 6 4 5 5}$ \\
\hline
\end{tabular}

No sites were selected in the Upper East, Upper West, Central, Western and the Greater Accra Region due to the amount of wind resource available in these regions. An area of 1081.155 $\mathrm{km}^{2}$ was defined as suitable by the NREL based on the wind resource alone (i.e. class 3 and higher zones). This represents about $0.45 \%$ of the country's total area. Incorporating the constraint and factor criteria reduced the area defined by the NREL to $454.6455 \mathrm{~km}^{2}(0.19 \%)$. The point locations of the selected sites are also shown in Fig. 12.

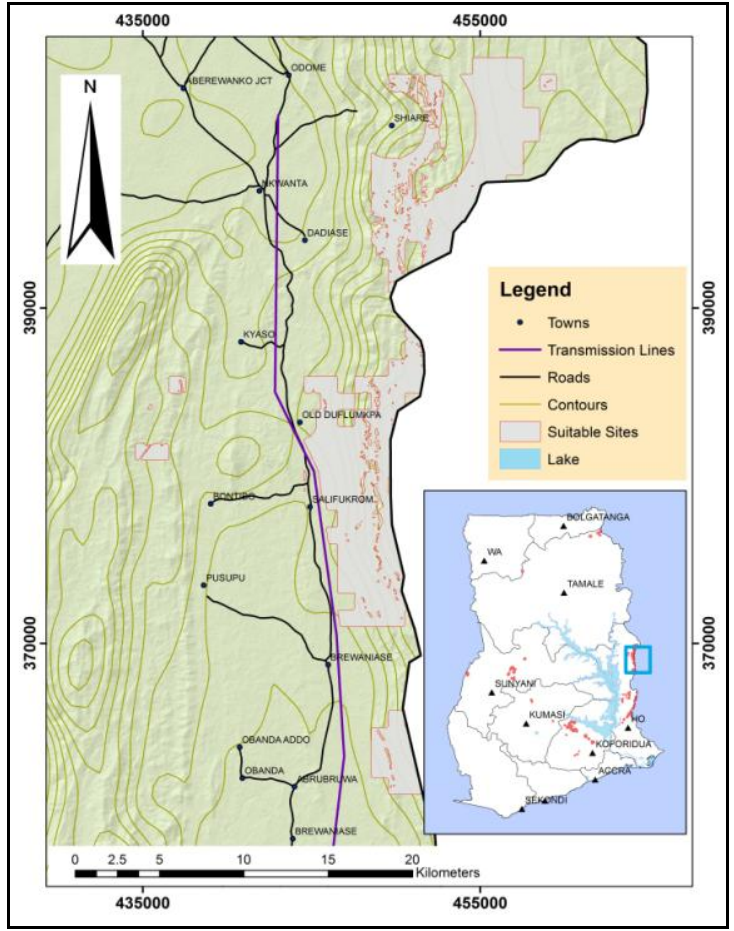

Fig. 11 A Section of Selected Sites in the Volta Region

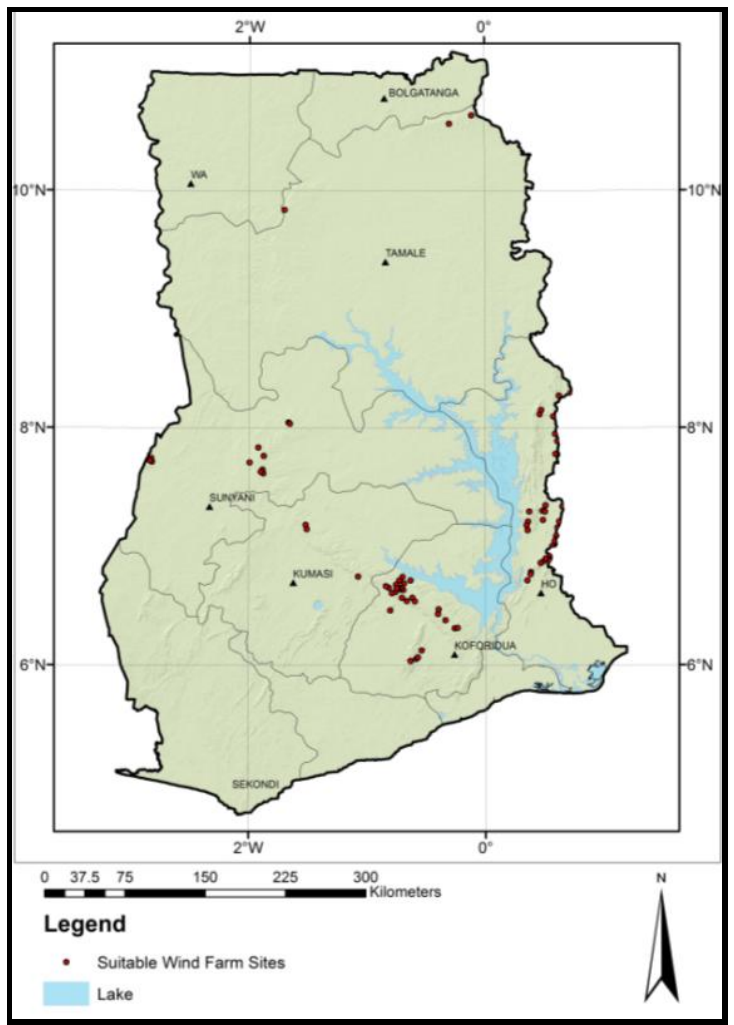

Fig. 12 Point Locations of the Selected Sites 


\section{Conclusions and Recommendations}

\subsection{Conclusions}

The various criteria for selecting suitable sites for wind farms have been identified. Factors needed were also identified and integrated them in the site selection process within a GIS environment. The site selection was based on two major kinds of criteria setting; the constraints and factor criteria. Layers of these criteria setting were combined using the overlay function in a GIS environment. Weights were also assigned to the factor criteria layers using pairwise comparisons. Suitable sites were selected in five regions after incorporating the various criteria.

The existing land use and ownership of the selected site should be ascertained. Consequently, these criteria can be adopted for any wind farm site selection at any part of the country.

A total of 142 isolated sites were selected after incorporating a number of factors and constraints.

\subsection{Recommendations}

It is recommended that:

(i) The existing and proposed land uses as well as land ownerships of the selected sites should be investigated before establishing the wind farm.

(ii) Wind speed measuring masts should be erected at the various sites selected to accurately ascertain the economic feasibility of developing a commercial wind farm.

(iii) The layout design for the other selected sites should also be designed for an optimum energy capture.

\section{References}

Anon. (2002), European Best Practice Guidelines for Wind Energy Development, European Wind Energy Association Special Publication, 26 pp.

Anon. (2005a), "Ghana Wind Energy Resource Mapping Activity", National Renewable Energy Laboratory, www.nrel.gov, Accessed: January 15, 2014.

Anon. (2005b), Guide to Electric Power in Ghana, $1^{\text {st }}$ edition, Resource Center For Energy Economics And Regulation, ISSER, University of Ghana, Legon, pp. $16-30$.

Anon. (2005c), "National Renewable Energy", www.nrel.org, Accessed: January 15, 2014.

Anon. (2010), "ArcGIS 10 Help Library", ESRI Inc., www.esri.com, Accessed: February 4, 2014.
Anon. (2012), "2010 Population and Housing Census", Ghana Statistical Service, www.statsghana.gov.gh, Accessed: January 10, 2014.

Anon. (2013), "Electricity Sector in Ghana", Wikipedia, www.en.wikipedia.org, Accessed: January 29, 2014.

Anon. (2013), "The Question: Where is Ghana", www.reportghananews.com, Accessed: February 8, 2014.

Anon. (2014), "Climate", Ghanaweb, www.ghanaweb.com/geography, Accessed: February 8, 2014.

Anon. (2014a), "NREL Class", National Renewable Energy Lab website, www.rredc.nrel.gov. Accessed: January 29, 2014.

Anon. (2014b), "Power Generation: Facts \& Figures", Volta River Authority website, www.vraghana.com/resources/facts, Accessed: March 28, 2014

Anon. (2014c), "Wind Power", National Geographic website, environment.national geographic.com. Accessed: February 8, 2014.

Anon. (2014d), "Wind Turbine" Wikipedia, www.en.wikipedia.org/wiki/. Accessed: January 29, 2014.

Antwi, E. (2011), "Renewable Energy Development Programme: Solar Power Project", Unpublished Report, Volta River Authority, pp. $5-6$.

Bennui, A., Rattanamanee, P. and Puetpaiboon, U. (2007), "Site Selection for Large Wind Turbine Using GIS", International Conference on Engineering and Environment, Songkhla, Thailand, pp. 1-2.

Carver, S. J. (1991), "Integrating Multi-Criteria Evaluation with Geographical Information Systems", International Journal of Geographical Information Systems, Vol. 5, No. 3, pp. 321-339.

Chaudhry, R. (2008), "Using Multi-Criteria Evaluation to Determine Suitable Sites for Developing Wind Farms in Massachusetts", Project Report, Clark University, Worcester, USA, $16 \mathrm{pp}$.

Dangermond, J. and Baker, J. (2010), "Climate Change is a Geographic Problem", GIS Best Practices: GIS for Climate Change, www.esri.com, Accessed: January 5, 2014.

Eastman, J. R., Jin, W., Kyem, P. A. K. and Toledano, J. (1995), "Raster Procedures for Multi-Criteria/Multi-Objective Decisions", Photogrammetric Engineering and Remote Sensing, Vol. 61, No. 5, pp. 539-547.

Klepinger, M. (2007), "Michigan Land Use Guidelines for Siting Wind Energy Systems", Extension Bulletin WO-1053, Michigan State University, Revised Ed, 19 pp. 
Kumi-Boateng, B. (2013), “Geographic Information Systems", Unpublished BSc Lecture Notes, University of Mines and Technology, Tarkwa, 119 pp.

Mahu, S. and Mawufemo, M. (2012), "Opportunities in the Ghana Renewable Energy Act 2011, Act 832”, Ministry of Energy, NRED, www.rredc.nrel.gov, Accessed: March 20, 2014.

Mallet, V. K. (2012), "Renewable Energy - What is Ghana's Wind Power Potential?", Arrakis Group website, www.arrakis-group.com, Accessed: January 20, 2014.

Moiloa, B. H. E. (2009), “Geographical Information Systems for Strategic Wind Energy Site Selection", Unpublished MSc Project Report, Vrije Universiteit Amsterdam, Amsterdam, Netherland, pp. $22-26$.

Neufville, L. (2013) "Wind Farm Site Suitability Selection using Multi-Criteria Analysis (MCA) and Spatial Modelling", Unpublished BSC Project Report, University of Technology, Jamaica, pp. $6-11$.

Nkrumah, F. (2002), "Feasibility Study of Wind Energy Utilization along the Coast of Ghana", Unpublished MSc Project Report, Kwame Nkrumah University of Science \& Technology, Kumasi, 78 pp.

Saaty, T. L. (2008), "Decision Making with the Analytic Hierarchy Process" Int. J. Services Sciences, Vol. 1, No. 1, pp. 83-98.

Talinli, I., Topuz, E., Aydin, E. and Kabakc1, S. B. (2011), "A Holistic Approach for Wind Farm Site Selection by Using FAHP”, Wind Farm Technical Regulations, Potential Estimation and Siting Assessment, Suvire, O. G. (ed), InTech., pp. 101-122.

Xu, L. and Yang, J. (2001), "Introduction to MultiCriteria Decision Making and the Evidential Reasoning Approach", Bulletin of Manchester School of Management, University of Manchester, No. 0106, pp. 30-55.

\section{Authors}

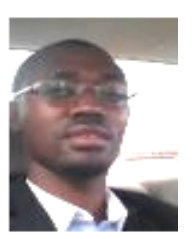

Derrick Sarpong holds a Bachelor of Science in Geomatic Engineering from the University of Mines and Technology. His main research interest is in knowing more about renewable energy using GIS and other geomatic techniques in solving some of their problems.

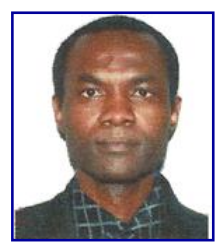

P. E. Baffoe holds MSc (Survey) from Moscow, and he is a Senior Lecturer at the Department of Geomatic Engineering, University of Mines and Technology. His research interests include application of GIS in Environmental Issues, 3D Modelling, Digital Photogrammetry and Mine Surveying. 